\title{
Assessing the Land Consolidation Projects from the Perspective of Farmers (A Case Study in Artova District of Tokat Province in Turkey)
}

\author{
Hayriye Sibel Gülse Bal ${ }^{1, a}$, Esra Kaplan ${ }^{1, b^{*}}$ \\ ${ }^{I}$ Department of Agricultural Economics, Faculty of Agriculture, Tokat Gaziosmanpasa University 60250 Tokat, Turkey \\ *Corresponding author

A R T I C L E IN F O A B S T R A C T \\ Research Article \\ Land consolidation is a powerful and effective tool in solving the fragmentation problem of \\ agricultural lands to form a larger, more rational and efficient land for the farmers. The benefits of \\ land consolidation projects are providing access to parcels, efficient use of water resources, real \\ location of parcels, and reducing the costs of irrigation and drainage projects. Although not \\ sufficiently successful, the land consolidation projects in Turkey had been initiated in 1961. This \\ study was aimed to measure and assess the knowledge, expectation and attitudes of farmers on the \\ land consolidation project planned to be implemented for some villages in Artova District of Tokat \\ Province, Turkey. The study was carried out in Taşpınar and Aşağı Güçlü villages which were \\ included in the consolidation program. In these villages, 62 farmers were selected by proportional \\ sampling method out of 175 producers registered in the Farmer Registration System (FRS) and, \\ face to face questionnaires were carried out with them. The results indicated that the producers \\ support the project primarily due to the convenience in irrigation and increasing the efficiency of \\ mechanization. Chi-square analysis revealed that the problems caused by disadvantages of \\ fragmented land structure, importance of land integrity and the experience on a previous \\ consolidation project area are important for the producers supporting the land consolidation project.
}

\section{Introduction}

Small size and fragmented structure of farms are the most important factors affecting the efficient and sustainable use of agricultural land in Turkey; thus, are the reasons of low yield per unit area. In addition to the total land assets used in agricultural production by the farms, the number of parcels, parcel size, and the distance between parcels affect the productivity in agricultural production. Studies have revealed that family income of individually owned large farms are higher compared to small farms, and therefore the increase in farm size contributes positively to the agricultural economy and the welfare of rural population (Deininger et al., 2004; Lerman and Cimpoies, 2006; Lerman and Shagaida, 2007). Positive effects of land consolidation on farm income have also been reported in studies conducted in Isparta and Konya provinces of Turkey (Mesci and Karlı, 2018; Oğuz and Bayramoğlu, 2004).

Land consolidation is a powerful and effective instrument in solving the fragmentation problem of agricultural lands to form a larger, more rational and efficient lands for the farmers. In other words, land consolidation is the combination of scattered and fragmented lands using modern management principles. Land consolidation can also be defined as the planned reorganization of the ownership model of parcels to form larger and rational land ownership. Improvement of infrastructure, implementation of development and environmental policies are also the other goals of the consolidation projects (Pasakarnis and Maliene, 2010).

Modern land consolidation practices in Western Europe started following the Second World War. The main goal was to develop the concept of equality between rural and urban living standards throughout Europe and to raise a strong awareness of war-induced food security. Agricultural policies till 1970s focused mainly on improving agricultural structures by reducing fragmentation and increasing farm sizes (Weiss and Maliene, 2004).

Proper management of water, soil, forest and wildlife and sustainable rural development are important issues in Europe. The policies point out that the global environmental issues are related to local land use and other 
practices (Pasakarnis and Maliene, 2010). European agriculture has achieved productive land consolidation, however, faces different needs. The European Union separates direct aid from the production level with new policies and supports stronger and sustainable use of natural resources due to the problems such as overproduction, poor agricultural incomes, rural abandonment and environmental pollution (EC, 2005, Palma et al., 2007).

Land consolidation, which can be defined as the consolidation of fragmented lands without any infrastructure work in a narrow sense, includes irrigation, drainage, transportation, soil-water conservation measures and various services required by rural settlements (Küsek, 2008). Thus, land consolidation, as an effective land management tool, not only brings solutions to the problems of land fragmentation, but also is a tool for rural development (Intensive, 2013).

In addition to small average farm size in Turkey, the distribution of lands is uneven. However, fragmentation of lands continues to be an increasing problem (Anonymous, 2010). Total number of parcels per farm in Turkey is 4.08 , and the average parcel size is $14.96 \mathrm{da}$. Decreasing of farm sizes and fragmentation of farms due to various reasons cause a significant decrease in productivity and profitability. Therefore, agricultural production cannot be possible economically in low farm sizes (Ekinci and Sayılı, 2010). The most important causes of the land fragmentation are fragmentation through inheritance, fragmentation by shared and divided sales, and fragmentation due to expropriation for various purposes (Beyazgül, 2012). The fragmentation of lands in Turkey has reached threatening levels, therefore, the land consolidation projects are inevitable to sustain agricultural production.

Land consolidation projects are aimed to correct land fragmentation and scattered problems that arise from population growth, inheritance, buying-selling, tenancy, and partnership, and to form farms at a suitable size. Land losses arising from roads and water channels and field boundaries in the fragmented structure is decreased by the land consolidation. In small parcels, the crop losses that may arise due difficulty in accessing to the field border during planting are decreased with the increase in average field sizes. After the completion of land consolidation, larger and smoother plots facilitate the use machinery in agricultural production. Since small and scattered parcels are combined together, the distance between the farm center and the parcels is shortened, accordingly, transportation costs are reduced and time, labor and fuel are saved. The number of parcel is decreased, the shape is improved and the size is increased by the land consolidation; therefore, agricultural inputs such as seed, fertilizer and pesticide are used at a more appropriate level. In the implementation of irrigation projects, the farmers will not use the old, scattered and misshapen parcel boundaries; thus, the investment costs will be decreased. Each parcel will have a border to the road and the canal, therefore, irrigation and transportation efficiency increase. The problems arising from the partnership in the parcels are eliminated. Border disputes between villages are eliminated by basing the village boundaries on fixed points. The scattered and common treasury land is combined and made ready for distribution. All services for rural areas such as environmental protection, erosion prevention, afforestation, village renewal, planning of all kinds of roads, village development plans, preparing land use plans can be planned and implemented with land consolidation projects. Lands required for public investments such as irrigation projects in the land consolidation project areas can be obtained from the parcels in the project area without expropriation by an appropriate deduction (Anonymous, 2014).

The first land consolidation was carried out in 1961 in Kargin village of Cumra district in Konya province of Turkey. The project included only the grouping of parcels. The consolidation projects from 1961 to 2002 was carried out on 450 thousand hectares land. Land consolidation activities gained a momentum with South Eastern Project (SEP) after 2009 and became a project covering 5 million ha land in 59 provinces. Land consolidation in 2012 was carried out on $1,210,604$ ha land. The share of GAP region within the total land area of consolidation in Turkey is approximately $44 \%$. Land consolidation projects are continuing in various provinces and Konya Plain, Eastern Anatolia, and Eastern Black Sea regions (Anonymous, 2014).

Land arrangement studies in Turkey are carried out by different legislation and institutions since 1973. The differences among institutions cause problems during implementations. The legal bases of land consolidation in Turkey are the Agricultural Reform Law on Land Arrangement in Irrigation Areas No 3083 and Soil Conservation and Land Use Law No 5403. The procedures and principles of land consolidations are regulated by the "Regulation on Conservation, Use and Land Consolidation of Agricultural Lands" published in the Official Gazette dated July 24, 2009 (Ceylan et al., 2014). Land consolidation studies within the scope of the Agricultural Reform on Land Arrangement in Irrigated Areas No. 3083, are carried out by the Ministry of Agriculture and General Directorate of Agricultural Reform. The implementing organizations within the scope of Soil Conservation and Use Law numbered 5403 are defined as the Ministry of Agriculture, Special Provincial Administrations, Municipalities and villages, legal entities such as cooperatives, unions and other public institutions operating for agricultural purposes (Çağdaş, 2010).

Many studies have been carried out in Turkey on land consolidation processes, practices, results of implementations and evaluation of farmer attitudes. Altıntaş (2006) revealed the socioeconomic structure of agricultural farms in the Erbaa plain of Tokat province where land consolidation was carried out. Kumbasaroğlu and Dağdemir (2007) examined the agricultural farms in the central district of Erzurum and determined the disadvantages arising from the fragmented and scattered lands of the farms. Küzec (2008) discussed the definition, the benefits and requirements of land consolidation, and examined the land consolidation studies conducted in Turkey and the legal procedures followed during these studies. Özer (2010) monitored and evaluated the situation after land consolidation in Yeniçiftlik village of Biga district of Çanakkale province. Sayılı and Ekinci (2012) determined the behaviors of farmers in three villages where land consolidations were completed within the scope of Samsun province Bafra Plain Left Coast Consolidation 
Project. Eser and Uçan (2012) investigated the effectiveness of the land consolidation projects applied in the village of Gedikli in Nurdağı district of Gaziantep province. Engindeniz (2012) examined the developments in land consolidations in Turkey and effects of land consolidation on rural development. Ceylan et al. (2014) assessed the impact of land consolidations in Turkey on sustainable family farming. Karakayacı et al. (2016) examined the effect of land consolidation on land value. Mesci and Karlı (2018) revealed the effects of land consolidation on agricultural farms, farmers' attitude towards consolidation, and social and economic benefits of land consolidation in Isparta province.

This study was aimed to assess the knowledge, expectation and attitudes of local farmers on the land consolidation project planned to be implemented for some villages in Artova District of Tokat Province, Turkey. In addition, the decisions of farmers on supporting the land consolidation project and the factors affecting the decisions of farmers were also determined in the study.

\section{Material and Method}

This study was carried out in 2019 in the villages of Artova District in Tokat Province, where land consolidation projects will take place. The aim of the study was to measure and assess the knowledge, confidence, expectation, attitudes and behaviors of local farmers on land consolidation. The primary data obtained from the surveys conducted with the local farmers constituted the main material of the study. The surveys were conducted as face-to-face questionnaires.

\section{Sampling Method}

The proportional sampling method, in which the sample volume is calculated according to the known and predicted ratio of those with a certain characteristic for a finite population, was used to determine the number of farmers to be interviewed. One hundred seventy-five farmers were determined registered in the FRS and producing in Iğdir, Taşpınar and Aşağı Güçlü villages of Artova District in Tokat Province where the land consolidation will be carried out. The sample volume was calculated as 62 using proportional sample size equation. Confidenece interval and margin of error were considered as 95 and $10 \%$, respectively. The ratio of producers who support and don't support the land consolidation is accepted as 0.50 . The proportional sample volume equation used to determine the sample volume is as follow (Newbold 1995, Miran 2003);

$$
\begin{aligned}
& \mathrm{n}=\frac{N * p *(1-p)}{(N-1) * \sigma_{p}^{2}+p *(1-p)} \\
& \sigma_{p}^{2}=\left(\frac{r}{Z_{\propto / 2}}\right)
\end{aligned}
$$

In the equation; $\mathrm{n}$ is the sample volume, $\mathrm{N}$ is the number of total producers, $\mathrm{P}$ is the ratio of producers to be included in the sample (The ratio of producers who support land consolidation is 0.50$), \sigma_{p}^{2}$ is the variance of the ratio, $\mathrm{r}$ is average acceptable margin of error, and $\mathrm{Z} \alpha / 2=\mathrm{z}$ is the table value.

\section{Statistical Analysis}

Statistical parameters of frequency (f) and percentage (\%) were used in the interpretation of some variables, while mean values were used to interpret other variables. Chisquare test was used to determine the relationship between variables. The chi-square test is one of the most widely used nonparametric tests (Özdamar 2004, Karacabey and Gökgöz 2009). The significance of the chi-square test indicates an important relationship between the two variables (Kaptan 1998). The chi-square analysis is used to test whether the relationship observed between variables in a crosstab is statistically significant (Sivasligil, 2003).

\section{Results and Discussion}

All the farmers participated in the study were male. Most of the farmers were in the age group of 26-33 $(24.19 \%)$ and followed by $42-49$ age group (22.58\%). Most of the farmers $(41.94 \%)$ were composed of elementary school graduates. Livestock breeding had the highest ratio (48.39\%) among the incomes of farmers followed by crop production (35.48\%). Most of the farmers (45.16\%) had an average monthly income between 1601 and 3000 TL. The average number of individuals in the family is 5.08, the number of brothers/sisters of the farmers is 4.4 , and the number of brothers living in the village and engaged in farming was 1.68. Half of the brothers have migrated from the village while half remained in the village. The brothers in the village did not leave the home, did not break their ties economically and continue living together in the same house. The most of the farmers (90.32\%) think that migration ratio in the village is very high.

The ownership status of the cultivated lands are given in Table 1. The landholders are in majority, and the producers have an average of 51.73 da irrigated and 40.62 da rainfed land.

The lands consist of 13.7 parcels and $72.58 \%$ of the producers prefer to have a single parcel instead of more than one parcel. The majority of farmers $(66.33 \%)$ stated that the fragmented parcel structure causes problems. The most important of problems are the increase in production costs (75.61\%) due to the distant lands, and secondly, the negative impact of fragmented lands on the use of machinery.

The results showed that $88.71 \%$ of the farmers are the members of a union or cooperative, and $90.91 \%$ of the farmers are members of Pankobirlik. After the completion of land consolidation project in the study area, $41.94 \%$ of the farmers primarily want to produce sugar beet. Most of the producers had an information on land consolidation. The minority with no information on land consolidation was also the farmers who were unaware of the trainings to inform the public. The main source of information for farmers is their friends and relatives (33.87\%) and followed by State Hydraulic Works personnel (27.42\%).

The majority of farmers $(79.03 \%)$ answered yes to the question on meetings, courses or seminars regarding the land consolidation project in their villages. However, information of the meetings on land consolidation projects have not reached to some farmers due to various reasons. While $41.94 \%$ of the farmers think that the announcements about land consolidation in general is insufficient, and $55.56 \%$ of the farmers participated to informative meetings think that the information provided at the meetings is insufficient. 
Table 1. Average land size and ownership status (da)

\begin{tabular}{l|cc}
\hline & Irrigated & Rainfed \\
\hline Landholder & 51.73 & 40.62 \\
Tenant & 17.64 & 7.48 \\
Partners & 1.13 & 0.16 \\
\hline Total & 70.79 & 49.97 \\
\hline
\end{tabular}

Table 2. The cooperatives and unions of which the farmers are the members

\begin{tabular}{l|l}
\hline \multicolumn{1}{c|}{ Unions } & $\mathrm{MS}(\%)$ \\
\hline Producer unions & 58.18 \\
Irrigation unions & 50.91 \\
Agricultural and credit cooperatives & 70.91 \\
Pankobirlik & 90.91 \\
\hline
\end{tabular}

MS: Membership status (\%), * Multiple choices have been marked.

Table 3. Knowledge of producers on land consolidation

\begin{tabular}{l|c}
\multicolumn{1}{c|}{ Knowledge status } & $\mathrm{P}$ \\
\hline Never heard about & 4.84 \\
I've heard but I don't know & 35.48 \\
I've heard and I know & 50.00 \\
I know and I have seen the example & 9.68 \\
\hline
\end{tabular}

P: Percent (\%)

Table 4. The reasons of producers who support the project

\begin{tabular}{l|c}
\hline \multicolumn{1}{c|}{ Reasons } & AS \\
\hline Land leveling for irrigation and drainage & 3 \\
Production costs will decrease & 2.6 \\
Access to the land will be provided & 2.6 \\
The number of land fragments will be decreased & 2.9 \\
Irrigation possibilities will be improved & 2.9 \\
Product loss will be reduced due to easy land access & 2.7 \\
The machine use will be easier & 2.9 \\
\hline
\end{tabular}

AS: Average Score, * Agree (3) - Undecided (2) - Disagree (1)

Table 5. The reasons of producers who don't support the land consolidation project

\begin{tabular}{l|c}
\hline \multicolumn{1}{|c|}{ Reasons } & AS \\
\hline $\begin{array}{l}\text { I do not think that the assessment will be carried } \\
\text { out fairly }\end{array}$ & 2.91 \\
$\begin{array}{l}\text { I do not think that it will have a positive effect on } \\
\text { crop yield }\end{array}$ & 2.68 \\
$\begin{array}{l}\text { I do not think that there will be a reduction in } \\
\text { production cost } \\
\text { Reallocated lands might be worse than my } \\
\text { current lands }\end{array}$ & 2.73 \\
$\begin{array}{l}\text { It may damage neighborhood and kinship } \\
\text { relationships in the village }\end{array}$ & 2.82 \\
\hline
\end{tabular}

AS: Average Score * I waste more (3) I am indecisive (2) - I waste less (1)

The results indicated that $44.44 \%$ of the farmers were aware of the right to appeal in their dissatisfaction with the land consolidation, while most of them did not know that they have the right to appeal. In addition, $61.29 \%$ of the farmers did not have information about the company that will carry out the land consolidation.

The results indicated that $66.13 \%$ of the farmers are aware of the problems caused by fragmented parcel structure, and $72.58 \%$ of them stated that they want to have a single parcel instead of more than one parcel. The problems caused by the land fragmentations were stated as increased production cost $(75.61 \%)$, difficulties in machinery use $(73.17 \%)$, problems in large scale production $(68.29 \%)$, distance to irrigation canals $(65.85 \%)$ and difficulties in accessing to parcels $(60.98 \%)$. Producers are aware of the problems arising from the fragmented parcel structure and complain about this situation. Some of producers $(37.10 \%)$ have visited a site where a land consolidation project was carried out before.

The ratio of farmers who support the land consolidation project is $64.52 \%$, while the ratio of farmers who do not support the project is $35.48 \%$. The factors affecting the decision of farmers on the project were evaluated by scoring with a triple likert.

Participants were aware of the benefits of the land consolidation project. However, the participants stated that they had hesitations as they did not have enough information about the project. The most important factor in supporting the project is land leveling for irrigation and drainage. Farmers who believe that irrigation opportunities will increase after the project, plan to cultivate sugar beet after land consolidation.

Possibility of damaging relationship between neighborhood and kinship was the most important reason of farmers for not supporting the project. Most of the farmers $(47.77 \%)$ stated that other people or factors affected their decision on the project. The results showed that $75.86 \%$ of farmers have been influenced by company responsible from the project and its personnel.

\section{Chi-Square Analysis}

The chi-square test was applied to determine the relationship between the positive or negative views of participants to the land consolidation project in their villages and the land fragmentation, problems due to the fragmentation of lands, and experience of farmers on visiting a previously consolidated land.

The integration possibility of fragmented lands into a single parcel with the land consolidation project made a significant difference in the positive thought of farmers to the project. The chi-square result (32.635) was statistically significant at $1 \%$ level (Table 6). The advantages of land integrity had a significant effect on positive approach of farmers to land consolidation project.

The relationship between the problems due to the fragmented parcel structure and the support of farmers for the consolidation project is given in Table 7 . The result of chi-square test (32.166) was statistically significant at $1 \%$ level. Yield, time and money losses due to the fragmentation of lands were important reasons for producers in supporting the land consolidation project.

The result of chi-square test (6.084) on the relationship between experience of farmers on visiting a previously consolidated land and their support for the land consolidation project was statistically significant (1\%) (Table 8 ). The experience on previously completed land consolidation project have made an important difference in the support of farmers to the project.

\section{Conclusion and Recommendations}

Land consolidation in Turkey introduced in 1961, and unfortunately the desired progress has not been reached in the last 60-year due to the problems on the most fundamental points. The quality and quantity of informative trainings in the project area are not sufficient to increase the support of farmers. 
Table 6. The relationship between importance of land integrity for producers and their support to the land consolidation project

\begin{tabular}{|c|c|c|c|c|c|c|c|}
\hline & & & \multicolumn{2}{|c|}{ Care for Land Integrity } & \multirow{2}{*}{ Total } & \multirow{2}{*}{$\chi^{2}$} & \multirow{2}{*}{$\mathrm{P}$} \\
\hline & & & Important & Not Important & & & \\
\hline Approach to the & \multirow{2}{*}{ Positive } & $\mathrm{N}$ & 38 & 1 & 39 & \multirow{4}{*}{32.635} & \multirow{4}{*}{$0.001 * * *$} \\
\hline Land & & $\%$ & 61.3 & 1.6 & 62.9 & & \\
\hline Consolidation & \multirow{2}{*}{ Negative } & $\mathrm{N}$ & 7 & 16 & 23 & & \\
\hline Project & & $\%$ & 11.3 & 25.8 & 37.1 & & \\
\hline \multirow{2}{*}{\multicolumn{2}{|c|}{ Total }} & $\mathrm{N}$ & 45 & 17 & 62 & & \\
\hline & & $\%$ & 72.6 & 27.4 & 100 & & \\
\hline
\end{tabular}

** and ***: Statistically important at 5 and $1 \%$ level, respectively.

Table 7. The relationship between the support of producers for the land consolidation project and the problems of the fragmented parcel structure

\begin{tabular}{|c|c|c|c|c|c|c|c|}
\hline & & & \multicolumn{2}{|c|}{$\begin{array}{c}\text { Fragmented Land Structure } \\
\text { Causes Problems }\end{array}$} & \multirow[t]{2}{*}{ Total } & \multirow{2}{*}{$\chi^{2}$} & \multirow[t]{2}{*}{$\mathrm{P}$} \\
\hline & & & Yes & No & & & \\
\hline \multirow{4}{*}{$\begin{array}{l}\text { Status of Support } \\
\text { on Land } \\
\text { Consolidation } \\
\text { Project }\end{array}$} & Yes I & $\mathrm{N}$ & 36 & 3 & 39 & \multirow{4}{*}{32.166} & \multirow{4}{*}{$0.001 * * *$} \\
\hline & support & $\%$ & 58.1 & 4.8 & 62.9 & & \\
\hline & No I do not & $\mathrm{N}$ & 5 & 18 & 23 & & \\
\hline & support & $\%$ & 8.1 & 29.0 & 37.1 & & \\
\hline \multicolumn{2}{|c|}{ Total } & $\begin{array}{l}\mathrm{N} \\
\%\end{array}$ & $\begin{array}{c}41 \\
66.1\end{array}$ & $\begin{array}{c}21 \\
33.9\end{array}$ & $\begin{array}{c}62 \\
100\end{array}$ & & \\
\hline
\end{tabular}

** and ***: Statistically important at 5 and $1 \%$ level, respectively.

Table 8. The relationship between experience of farmers on visiting a previously consolidated land and their support for the land consolidation project

\begin{tabular}{|c|c|c|c|c|c|c|c|}
\hline & & & \multicolumn{2}{|c|}{$\begin{array}{l}\text { Visiting a Sample Place } \\
\text { Previously Consolidated }\end{array}$} & \multirow[t]{2}{*}{ Total } & \multirow[t]{2}{*}{$\chi^{2}$} & \multirow[t]{2}{*}{$\mathrm{P}$} \\
\hline & & & Yes & $\mathrm{No}$ & & & \\
\hline \multirow{4}{*}{$\begin{array}{l}\text { Support Status of } \\
\text { Land } \\
\text { Consolidation } \\
\text { Project }\end{array}$} & Yes I & $\mathrm{N}$ & 19 & 20 & 39 & \multirow{4}{*}{6.084} & \multirow{4}{*}{$0.014 * *$} \\
\hline & support & $\%$ & 30.6 & 32.3 & 62.9 & & \\
\hline & No, I don’t & $\mathrm{N}$ & 4 & 19 & 23 & & \\
\hline & support & $\%$ & 6.5 & 30.6 & 37.1 & & \\
\hline \multicolumn{2}{|c|}{ Total } & $\begin{array}{l}\mathrm{N} \\
\%\end{array}$ & $\begin{array}{c}41 \\
37.1\end{array}$ & $\begin{array}{c}21 \\
62.9\end{array}$ & $\begin{array}{c}62 \\
100\end{array}$ & & \\
\hline
\end{tabular}

** and ***: Statistically important at 5 and $1 \%$ level, respectively.

The findings of this study, conducted in some villages of Artova District of Tokat Province, showed that a significant portion of the farmers $(40.32 \%)$ had never heard of or had no information about the land consolidation project prior to the implementation. Therefore, the participation of all the farmers in the region to informative meetings should be ensured to convince the farmers and get their support on the project. In addition, contribution of project staff to inform the farmers about the project was found low. The information sources of farmers are their friends-relatives $(33.87 \%)$, followed by State Hydraulic Works personnel $(27.42 \%)$. The studies carried out in different parts of the Turkey have also revealed that most of the farmers had not been informed sufficiently prior to the implementation of the project, and majority of them did not know the goal and content of the consolidation projects carried out in their regions. The reports of previous studies have emphasized the importance of training and extension activities and suggested to increase and continue these activities to create positive perspectives on land consolidation (Kızılaslan and Almus, 2001; Aktaş et al., 2003; Arslan and Değirmenci, 2016; Mesci and Karlı, 2018). Despite the results of studies and the 60 years of time, the effectiveness of information activities is still insufficient. Therefore, the activities to inform the farmers about land consolidation should be planned and carried out again in a way to achieve the goal and the farmers should be informed in the most correct way from the first hand. Increasing the number of informative meetings, ensuring that the producers are informed about land consolidation and being more sensitive to the farmers will increase the trust to the company staff and the project and facilitate the implementation.

The ratio of farmers who support the land consolidation project was $64.52 \%$, while $35.48 \%$ of them did not support the project. Participants are aware of the benefits of the land consolidation project. However, they had some reservations due to the lack of adequate information about the project. The most important factor in supporting the project by the farmers is the land leveling for irrigation and drainage. Most of the farmers $(66.13 \%)$ were aware of the problems caused by the fragmented parcel structure, and $72.58 \%$ of the farmers stated their desire to have a single parcel instead of more than one parcel. The problems caused by fragmented lands are stated as the increase in the production cost, the difficulty in the use of machinery, the prevention of large-scale production, the distance to the irrigation canals and the difficulties in accessing to the fields. In other words, farmers are aware of the problems caused by the fragmented parcel structure; therefore, they support the land consolidation project. 
The expected decrease in production costs was an important factor in farmers' support for land consolidation project. Chi-square analysis indicated that producers who consider fragmented lands to cause various problems and care about land integrity make a significant difference in supporting the project.

The most important reason of the farmers' negative opinion on the land consolidation project was their concern that the land consolidation may negatively affect the neighborhood and kinship relations in the village. In addition, some farmers who did not support the project stated that land evaluations may not be carried fairly. Some negativities experienced in the consolidation project carried out in the Güzelbeyli village within the scope of the study led to a bad example and created discomfort and uneasiness among the farmers.

Natural resource management considering some ecological issues and environmental conservation is supported worldwide to achieve the sustainable development of rural areas with a comprehensive approach to land consolidation. Inappropriate land consolidation is accepted as the main causes of the fragmentation of natural ecosystems, decrease in biodiversity, wind and water erosion; therefore, improvements are focused in this direction (Lisec et al., 2005).

In most Western European countries, land consolidation has been considered an important tool in land management and an integral part of a broader rural development 'package' over the past 15 years (Weiss and Maliene, 2004, Hartvigsen, 2005). In Western European countries, land consolidation deals with environmentally friendly and sustainable land management rather than economical focus (Thomas, 1998). The harmonization policy in the EU, where land consolidation is promoted as an indispensable measure for integrated rural development, has gained momentum (Thomas, 2006a , Thomas, 2006b ).

Agriculture and food security issues have become at the utmost importance in the world; therefore, Turkey should care more on productivity of soils and consolidation activities. In the consolidation model and national land consolidation strategy, compliance with local, national and European land consolidation policies should be taken into account and rapid progress is needed for nationwide land consolidation projects. Many things and the lifestyles of societies are changing rapidly in the world, yet the lands of a country will remain the most valuable natural asset that will be inherited to next generations as happened before.

\section{Statement Summary for Contribution Ratio of Researchers}

The authors contributed equally to the paper.

\section{Conflict of Interest Statement}

There is no conflict of interest between the authors of paper.

\section{References}

Arslan F, Değirmenci H. 2016. "Perspective of the farmers on the land consolidation project: Kahramanmaraş Türkoğlu district and villages". Journal of Uludağ University Faculty of Agriculture,30(2): 23-34. (in Turkish)
Aktaş E, Bilgili ME, Akbay AÖ, Bal T. 2003. Determining SocioEconomic Factors Affecting the Land Consolidation Decision in Yemişli Village of Karataş District in Adana Province. Turkey VII. Agricultural Economics Congress. (in Turkish)

Altıntaş G. 2006. A Research on Economic Analysis of Agricultural Farms in Land Consolidation Areas and Determining Optimum Production Plans in Tokat Province Erbaa Plain. PhD Thesis. Tokat. 2006. (in Turkish)

Anonymous. 2014. Website of the General Directorate of Land Registry and Cadaster, (Accessed March 2019)

https://www.tkgm.gov.tr/.../arazi_toplulastirmasi3083_ve_5403 _sayili_kanunlar.pptx(tapu_(in Turkish)

Anonymous, 2010. Ministry of Development website. (Accessed March 2019). https://www.google.com/search?q=kalk\%C4\% B1nma+bakanl\%C4\%B1\%C4\%9F\%C4\%B1+2014\&oq=kal $\mathrm{k} \% \mathrm{C} 4 \% \mathrm{~B} 1 \mathrm{nma}+\& \mathrm{aqs}=$ chrome.0.35i39j0j69i57j69i59j35i39 j0.6863j0j7\&sourceid=chrome\&ie=UTF-8_(in Turkish)

Beyazgül M. 2012, "The Legal Division of Agricultural Lands in Turkey “, Technical Report of the Ministry of Food, Agriculture and Livestock, Ankara. (in Turkish)

Ceylan RF, Sayın C, Özalp M. 2014. "The effects of Current Land Consolidation Policy in Turkey on Sustainable Family Farming Model", the National Family Farming Symposium, pp 137-508 30-31 October, Ankara. (in Turkish)

Çağdaş V. 2010. Rural Land Regulation. Lecture Notes, Yıldız Technical University, İstanbul. (in Turkish)

European Commission EC. 2005. Lisbon Strategy-Putting Rural Development to Work for Jobs and Growth. European Commission, Brussels.

Ekici K, Say1lı M. 2010. A Study on the Legislation Regarding Preventing the Fragmentation of Agricultural Lands, Gaziosmanpaşa University Faculty of Agriculture Journal, 27 (2), 121-129. (in Turkish)

Engindeniz DY. 2012. Evaluation of Land Consolidation Studies in Turkey in terms of Rural Development. 10. National Agricultural Economics Congress. 5-7 September, Konya.

Eser Ö, Uçan K. 2012. Determination of Land Consolidation Efficiency. KSU Journal of Natural Sciences, 15(2): 38-45. (in Turkish)

Deininger K, Sarris A, Savastano S. 2004. Rural land markets in transition: evidence from six Eastern European Countries. Quarterly Journal of International Agriculture 43, 361-390

Hartvigsen M. 2005. Land consolidation pilot projects in Eastern Europe. In: International

Land Consolidation Conference, December 1-2, Budapest, Hungary.

Kaptan S. 1998. Scientific Research and statistical techniques. Ankara: Tekışık Web Offset Facilities. (in Turkish)

Karacabey A, Gökgöz F. 2009. A Nonparametric Performance Analysis for the Turkish Real Sector: "Gem-Flex" Approach. Mediterranean FEAS Journal, 09 (17): 72-104.

Karakayacı Z, Aydın A, Gönül C, Uğur E. 2016. The Effect of Land Consolidation on Land Value; Example of Alanözü Town in Konya Province. Mustafa Kemal University Journal of the Faculty of Agriculture 21(2): 157-167 (in Turkish)

Kizilaslan N, Almus S. 2001. Tendencies of Farmers in Land Consolidation (Tokat-Zile Güzelbeyli Example), GOU. Journal of the Faculty of Agriculture, 18(1): 51-60. (in Turkish)

Kumbasaroğlu H, Dağdemir V. 2007. Economic Analysis of Agricultural Farms for Fragmenttaion of Agricultural Lands in Central District of Erzurum Province. Atatürk University Journal of the Faculty of Agriculture 38(1): 49-58, 2007, ISSN: 1300-9036. (in Turkish)

Küsek G. 2008. "Land Consolidation". General Directorate of Agricultural Reform, II. Cadaster Congress, Ankara. (in Turkish)

Küzeci N. 2008. Land consolidation studies in Turkey during the European Union Accession Process. Master Thesis. Erzurum. Ankara. (in Turkish) 
Lerman Z, Cimpoies D. 2006. Land consolidation as a factor for rural development in Moldova. Europe-Asia Studies 58, $439-455$.

Lerman Z, Shagaida N. 2007. Land policies and agricultural land markets in Russia. Land Use Policy 24, 14-23

Mesci O, Karli B. 2018. Socio-Economic Analysis of Agricultural Enterprises in Land Consolidation Areas in Isparta Province. Mustafa Kemal University Journal of the Faculty of Agriculture, 23 (1): 106-114.

Miran B. 2003. Statistics. Ege University Publication Press, ISBN 975-9308800 Bornova İzmir. 2013. (in Turkish)

Newbold P. 1995. Statistics for Business and Economics. Prentice-Hall International, New Jersey.

Oğuz C, Bayramoğlu Z. 2004. The Effect of Different Parcel Sizes on Unit Costs After Land Consolidation in Çumra District of Konya Province; Küçükköy Sample, S.Ü. Journal of the Faculty of Agriculture. 18(34): (2004) 70-75. (in Turkish)

Özdamar K. 2004. Statistical Data Analysis with Software Packages, Kaan Bookstore, Expanded 5th Edition, (in Turkish)

Özer A. 2010. Monitoring and Evaluation of the Situation Following Land Consolidation in Yeniçiflik Village of Biga District in Çanakkale Province, Master Thesis. Çanakkale. (in Turkish)

Palma J, Graves AR, Burgess PJ, van der Werf W, Herzog F. 2007. Integrating environmental and economic performance to assess modern silvoarable agroforestry in Europe. Ecological Economics 63, 759-767
Pasakarnis G, Maliene V. 2010. Towards sustainable rural development in Central and Eastern Europe: Applying land consolidation, Land Use Policy 27 (2010) 545-549

Say1l M, Ekinci K. 2012. Determination of Farmer Behaviors in Bafra Plain of Samsun Province Land Consolidation Project and Socio-Economic Benefits of the Project. TEPGE Publication No 202, p. 86, Ankara. (in Turkish)

Sivaslıgil AC. 2003. Research Techniques and Basic Statistics, İzmir, Nadir Bookstore. (in Turkish)

Thomas J. 1998. Non-polluting land use and sustainable development in rural regions support through land consolidation and village renewal. In: International Federation of Surveyors, FIG Commission 7-Symposium, Brighton, UK.

Thomas J. 2006a. Attempt on systematization of land consolidation approaches in Europe. Zeitschrift fur Geodasie Geoinformation und Land management (ZfV) 131, 156-161.

Thomas J. 2006b. Property rights, land fragmentation and the emerging structure of agriculture in Central and Eastern European countries. Electronic Journal of Agricultural and Development Economics Food and Agriculture Organization 3: 225-275.

Weiss E, Maliene V. 2004. Flurbereinigung in der Bundesrepublik Deutschland. Technika, Vilnius

Yoğunlu A. 2013. "Land Consolidation Activities, TRB1 Region (Bingöl, Elazı̆g, Malatya,Tunceli) http://www.fka.org.tr/ ContentDownload/toplula\%C5\%9Ft\%C4\%B1rma.pdf (in Turkish) 